\title{
FANCM Gene
}

National Cancer Institute

\section{Source}

National Cancer Institute. FANCM Gene. NCI Thesaurus. Code C54228.

This gene plays a role in transcriptional regulation and ubiquitination. 